\title{
Growth and Yield Performance of Selected Lowland Rice Varieties under Alternate Wet and Dry Water Management
}

\author{
Melanie D. Ratilla and Ulysses A. Cagasan \\ Department of Agronomy and Soil Science, Visayas State University, Baybay City, \\ Leyte 6521-A, Philippines
}

\begin{abstract}
Severe water shortage in many parts of the world has caused enormous yield losses in rice. To continue feeding the increasing number of people who are dependent on rice as staple food, there is a need to address the problem on water shortage. One possible solution may be the application of alternate wet and dry (AWD) water management in rice production.

This experiment was conducted to evaluate the growth and yield performance, as well as the profitability of selected lowland rice varieties under AWD water management. An experimental area of $450 \mathrm{~m} 2$ with Umingan clay loam soil was laid out in randomized complete block design (RCBD) with three replications. Each replication was subdivided into six treatment plots with an area of $20 \mathrm{~m} 2(5 \mathrm{~m} \mathrm{x} 4 \mathrm{~m})$ each. The treatments were: T1 - Masipag 45 (M45), T2 - Matatag 6 (M6), T3 - Masipag 129-2 (M129-2), T4 - Pinili-1, T5 -SL-8H and T6 - PSBRc-18 (check variety). Results showed that number of days from planting to heading and maturity, fresh straw yield ( $\mathrm{t}$ ha-1), number of productive tillers per hill, number of filled grains per panicle and grain yield ( $\mathrm{t}$ ha-1) differed significantly among treatments $(\mathrm{p}<0.05)$. Pinili- 1 headed and matured the earliest and produced the highest fresh straw yield ( $\mathrm{t}$ ha-1). However, M-129-2 and Matatag 6 had the highest number of productive tillers per hill, number of filled grains per panicle and total grain yield ( $t$ ha-1) which surpassed that of PSBRc18 (check variety). Masipag129-2 and Matatag 6 also gave the highest net profit of Php 23,805.00 per hectare.
\end{abstract}

Keywords: lowland rice production, genetic variability, water management practices, cost and return analysis

Correspondence: Ulysses A. Cagasan Address: Department of Agronomy and Soil Science, Visayas State University, Baybay City, Leyte, 6521-A Philippines. Tel: +63-053-335-2627. Email: uly_cagasan@yahoo.com

DOI: 10.32945/atr3327.2011 


\section{INTRODUCTION}

In the Philippines and in many other parts of the world, rice (Oryza sativa L.) is one of the most important crops cultivated by farmers. In most parts of Asia, according to Facon (2000), rice is not only a staple food; it also serves as the major source of livelihood and income of the rural people.

Although rice is grown in different ecosystems, $78 \%$ of the world's rice is grown under irrigated or rainfed lowland conditions (IRRI, 1997). As pointed out by Virk et al. (2004), irrigated transplanted rice on puddled soil is still the traditional system practiced over several centuries in Asia. This traditional rice production system, according to Lampayan et al. (2004), requires much water. In fact, it consumes more than $50 \%$ of all irrigation water used in the region. However, they pointed out that water resources are now increasingly becoming scarce and expensive. Facon (2000) noted that reduced investments in irrigation infrastructure as well as increased competition for water and large withdrawals from underground water could lower the sustainability of rice production. Thus, to be able to continue producing rice that can feed the increasing world population, there is a need to develop alternative rice production systems that require less water and increase water productivity.

In the 1990s, researchers from the International Rice Research Institute (IRRI) and some national researchers successfully tested several water-saving technologies such as saturated soil culture, saturated soil and soil drying, and alternate wetting and drying (AWD) in farmers' fields (Virk et al., 2004). Facon (2000) reported that intermittent flooding, maintaining the soil in sub-saturated condition, and alternate drying and wetting can reduce water applied to the field by more than 40 percent compared with continuous submergence methods without affecting the grain yields. He said that increases in grain yields by up to 20 percent were actually reported. Vial (2007) also reported that aerobic and AWD systems have significantly increased water use efficiency of rice in more permeable soils such as in northern China.

Belder et al. (2004), however, reported that when tested in tropical areas like India and the Philippines, AWD was found to cause reduction in rice yield. One factor that may have contributed to yield loss under AWD 
method is the use of inappropriate variety. Virk et al. (2004) evaluated several elite inbred lines, varieties, and hybrids to be able to identify genotypes that would give high yields even under AWD system. They found that genetic variability for tolerance to relatively mild water stress conditions existed in both inbred and hybrid rice varieties. Specifically, they observed that yield losses due to AWD vary from $3-23 \%$ for hybrids, and from $6-26 \%$ for inbreds. This yield variation needs to be further evaluated. Thus, this study was conducted to evaluate the growth and yield performance of lowland rice varieties under alternate wet and dry (AWD) water management; determine which lowland rice varieties would give the optimum grain yield under AWD water management; and evaluate the profitability of growing lowland rice varieties under AWD water management.

\section{MATERIALS AND METHODS}

This study was conducted in the experimental field of the Department of Agronomy and Soil Science in the Visayas State University (VSU), Baybay City, Leyte, Philippines. An area of $450.5 \mathrm{~m} 2$ with an Umingan clay loam soil was selected. The field was flooded for seven days at a depth of 5-6 cm and was plowed and harrowed two times at weekly interval to allow the weeds and rice stubbles to decompose. The paddies were puddled and then leveled using leveling boards. After the last harrowing, levees were constructed to avoid fertilizer loss and contamination of treatments. All treatments were subjected to AWD, so no plot was prepared for rice cultivated under normal culture.

Before transplanting the rice seedlings, 10 soil samples were collected at random from the experimental area at a depth of 0-20 cm. After harvest, five soil samples were also collected from each treatment plot. The same procedures were used in the initial and final soil analyses. The soil samples were composited, air-dried, pulverized and sieved using a 2-mm wire mesh. Soil $\mathrm{pH}$ was measured potentiometrically in soil/solution suspensions of 1:2.5 $\mathrm{H}_{2} \mathrm{O}$. The organic carbon content was determined using Walkley-Black method, while the available $\mathrm{P}$ was determined using Bray No. 2 method. Exchangeable K, particle 
size distribution (analyzed using the hydrometer method), and water holding capacity were all determined following the methods described in a handbook on 'Standard Methods of Analysis for Soil, Plant Tissue, Water and Fertilizer' prepared by PCARRD (1980).

The experiment was laid out in Randomized Complete Block Design with three replications. Each replication was divided into six treatment plots, each plot measuring $4 \mathrm{~m} \times 5 \mathrm{~m}\left(20 \mathrm{~m}^{2}\right)$. Each plot had 20 rows. Alleyways of $1 \mathrm{~m}$ between replications and $0.5 \mathrm{~m}$ between plots were provided to facilitate farm operations and data gathering. The treatments were designated as follows: T1 - Masipag 45 (M45); T2 - Matatag 6 (M6); T3 - Masipag 129-2 (M129-2); T4 - Pinili-1 (P1); T5 - SL-8H (hybrid); and T6 - PSB-Rc18 (check variety). These test varieties are known to the Visayan farmers because of their acceptable characteristics such as resistance to insect pest and diseases, good eating quality and moderately high yielding ability, and ability to adapt to wide range of agro-climatic conditions, including lack of water. The PSB-Rc18 was used as checked variety since it is recommended by the Philippine Seed Board, is adapted to a wide range of agro-climatic conditions, and is already popularly used by farmers in the Visayas region. Seeds of the selected rice varieties were secured from the Department of Agronomy and Soil Science (DASS) in VSU, Baybay City, Leyte, Philippines. A total of 250 grams dried seeds of each rice variety was weighed, placed in bags, labeled, and were stored in a cool dry place before soaking.

Wet seedbed was constructed at $4 \mathrm{~cm}$ high, $1 \mathrm{~m}$ wide and $2.5 \mathrm{~m}$ long for each rice variety. Before soaking, rice seeds were re-dried for 2 hours to break the dormancy. The seeds were soaked in water for 24 hours, and then incubated for 36 hours to allow the seeds to germinate before sowing in the seedbed. The seedbed for each variety had an area of $1 \mathrm{~m} \times 2.5 \mathrm{~m}\left(2.5 \mathrm{~m}^{2}\right)$, considering a seeding rate of $100 \mathrm{~g} \mathrm{~m}^{-2}$. Water level was maintained at $5 \mathrm{~cm}$ depth for 5 days after sowing the seeds to minimize drying of the field so that pulling of the seedlings during transplanting would not be difficult.

Each treatment plot was applied with fertilizer at the rate of 9030-30 kg N, $\mathrm{P}_{2} \mathrm{O}_{5}$ and $\mathrm{K}_{2} \mathrm{O}$ per hectare. Basal fertilizer application of one half of $\mathrm{N}$ and all of $\mathrm{P}_{2} \mathrm{O}_{5}$ and $\mathrm{K}_{2} \mathrm{O}$ was done using $0.43 \mathrm{~kg} / \mathrm{plot}$ of 
complete fertilizer. The remaining $\mathrm{N}$ was applied using urea (45-0-0) at $0.13 \mathrm{~kg} / \mathrm{plot}$ by top dressing at panicle initiation stage. Fifteen day-old seedlings of the rice varieties used for this study were transplanted in the designated plots at the rate of 2-3 seedlings/hill at a distance of $25 \mathrm{~cm}$ between hills. Missing hills were replaced one week after transplanting to maintain the recommended plant population of $16 \mathrm{hills} / \mathrm{m} 2$.

Weeding operation using rotary hand-weeder was done in the entire experimental area 10 days after transplanting to control weeds. Spot weeding and cleaning of the dikes were also done whenever necessary to keep the experimental plots clean.

Alternate wet and dry (AWD) water management system was started one week after transplanting by flooding the plots for 1 day, then draining for 5 days. The experimental area was flooded again and the cycle was repeated until reproductive stage. At reproductive stage the plots were kept flooded ( $5 \mathrm{~cm}$ depth) until two weeks before harvest. The whole area was drained 2 weeks before harvest to facilitate harvesting operation. The dates and frequency of applying irrigation water were recorded during the whole duration of the experiment.

Golden snails (Pomacea canaliculata L.) were controlled by handpicking the adults, young and egg clusters. This was done in the area before and after transplanting of the seedlings. During seedling stage, Furadan $3 \mathrm{G}$ was applied at a rate of $16 \mathrm{~kg} / \mathrm{ha}$ to control leafhoppers. During heading and soft dough stages, smell traps using fish entrails or crushed golden snails were placed inside a fine screened mesh and hanged at strategic places around the experimental area to attract bugs. The trapped bugs were burned early in the morning and late afternoon using a torch made of dried coconut leaves. To minimize grain loss due to birds like 'gorion' (Passer montanus) and 'maya' (Lonchura malacca), a person was assigned to guard the plants during heading up to harvesting stage.

Harvesting was done when approximately $90 \%$ of the grains in each plot had ripened as indicated by the amber color and firmness of the grains. The panicles from the harvestable area were cut at the base of the panicle (approximately $30 \mathrm{~cm}$ ) with a sharp sickle. 


\section{Data Gathered}

The following agronomic characteristics were evaluated: number of days from transplanting to heading and maturity; plant height $(\mathrm{cm})$ at harvest; fresh straw yield ( $\left.\mathrm{t} \mathrm{ha}^{-1}\right)$ and leaf area index (LAI). For the yield and yield components, the following parameters were measured: number of productive tillers per hill, number of filled grains per panicle, number of unfilled grains per panicle, weight of 1,000 grains (grams) and total grain yield $\left(\mathrm{t} \mathrm{ha}^{-1}\right)$. Harvest index was calculated as the ratio of the economic yield and biological yield. Initial and final soil analyses and production cost and return analysis were also done.

\section{RESULTS AND DISCUSSION}

\section{Soil Chemical Analysis}

Initial soil analysis showed that the experimental area had a soil $\mathrm{pH}$ of $4.95,4.62 \%$ organic matter, $20 \mathrm{mg} / \mathrm{kg}$ available $\mathrm{P}, 126 \mathrm{mg} / \mathrm{kg}$ exchangeable $\mathrm{K}$, and $72 \%$ water holding capacity (Table 1 ). Results of the particle size distribution analysis showed that the soil contained 39\% sand, $30 \%$ silt, and $31 \%$ clay. These indicate that although the soil in the experimental field had high organic matter content, high amounts of available $\mathrm{P}$ and high exchangeable $\mathrm{K}$, and high water holding capacity, it was very acidic, This high level of soil acidity resulted to poor growth performance of the rice plants as manifested by the yellowing of leaves during the early stages of growth. The application of inorganic fertilizer to the experimental field improved the condition of the soil which favored the development of more number of tillers per hill and more number of filled grains per panicle, which eventually resulted to high grain yields of some test varieties.

In the final soil analysis, results revealed that the $\mathrm{pH}$ of the soil in the experimental area slightly increased, while the organic matter content, available $\mathrm{P}$, and exchangeable $\mathrm{K}$ slightly decreased. This means that soil acidity level slightly decreased. The slight increase in soil $\mathrm{pH}$ could be 
attributed to the high amount of organic matter and reducible iron in the soil and the suspension effect of flooded soils. On the other hand, the slight decrease in organic matter content could be due to the organic matter decomposition and the decrease in available $\mathrm{P}$ and exchangeable $\mathrm{K}$ brought about by the absorption of $\mathrm{P}$ and $\mathrm{K}$ ions by the plants.

Table 1. Initial and final soil analyses of the experimental area planted to lowland rice varieties under AWD water management.

\begin{tabular}{|c|c|c|c|c|}
\hline & Soil $\mathrm{pH}$ & $\begin{array}{l}\mathrm{OM} \\
(\%)\end{array}$ & $\begin{array}{c}\text { Available } \\
\text { Phosphorus } \\
\text { (mg/kg) }\end{array}$ & $\begin{array}{c}\text { Exchangeable } \\
\text { Potassium } \\
(\mathrm{mg} / \mathrm{kg})\end{array}$ \\
\hline Initial Soil Analysis & 4.95 & 4.62 & 19.64 & 125.85 \\
\hline \multicolumn{5}{|l|}{$\underline{\text { Final Soil Analysis }}$} \\
\hline $\mathrm{V}_{1}=$ Masipag 45 (M 45) & 5.31 & 3.91 & 9.92 & 119.25 \\
\hline $\mathrm{V}_{2}=$ Matatag $6(\mathrm{M} 6)$ & 5.15 & 4.03 & 9.84 & 110.67 \\
\hline $\mathrm{V}_{3}=$ Masipag 129-2 (M-129-2) & 5.05 & 3.82 & 11.55 & 105.53 \\
\hline $\mathrm{V}_{4}=$ Pinili-1 $(\mathrm{P} 1)$ & 5.13 & 4.41 & 9.77 & 107.23 \\
\hline $\mathrm{V}_{5}=\mathrm{SL}-8 \mathrm{H}$ & 5.14 & 4.09 & 9.94 & 104.73 \\
\hline $\begin{array}{c}\mathrm{V}_{6}=\text { PSBRc18 } \\
\text { (check) }\end{array}$ & 5.08 & 3.52 & 8.37 & 146.80 \\
\hline
\end{tabular}

\section{Agronomic Characteristics}

Plant height and LAI of the rice varieties grown under AWD water management did not differ significantly (Table 2). However, significant differences $(p<0.05)$ were observed on the number of days from transplanting to heading and maturity, and on fresh straw yield $(\mathrm{t}$ ha $\left.^{-1}\right)$. All varieties headed and matured earlier than the check variety (73 DAT), but Pinili-1 headed the earliest at 52 days after transplanting (DAT) and matured the earliest at 85 DAT. Two varieties, M129-2 and PSB Rc18 (check variety), matured beyond 100 DAT with PSB-Rc18 having headed (73 DAT) and matured (103 DAT) the latest. This marked variation in maturity period could be attributed to the test varieties'genetic differences and their different responses to the AWD water management. Normally, PSB-Rc18 matures in 120 days (4 months). However, in this study, the variety matured earlier (103 DAT). This result supports the 
findings of Virk et al. (2000) which showed that genetic variability for tolerance to relatively mild water stress conditions exists in both inbred and hybrid rice varieties. This also conforms with the findings of Tripoli (2006) which showed that AWD water management resulted in early maturity of lowland rice. This further supports the findings of Caintic (2004) that Masipag rice varieties significantly headed and matured earlier than the other test varieties, while SL-8H and PSBRc 18 headed and matured later.

Fresh straw yield also differed significantly $(p<0.05)$ among varieties (Table 2). PSB-Rc18 produced the heaviest straw yield (22.84 $\mathrm{t} \mathrm{ha}^{-1}$ ), followed by M-129-2 (20.56 $\left.\mathrm{t} \mathrm{ha}^{-1}\right)$ and Pinili-1 (20.67 tha-1). The significantly higher fresh straw yields of these varieties could probably be due to the higher number of tillers with broader leaves that they were able to produce during the vegetative stage compared to the other varieties (Table 2). This result conforms with findings of Akita (1987) which showed that Rc18 and Masipag rice varieties have high tillering capacity, and are more responsive to nitrogen application thereby giving higher fresh straw yield than the other varieties.

Table 2. Agronomic characteristics of lowland rice varieties under AWD water management

\begin{tabular}{|c|c|c|c|c|c|}
\hline \multirow[t]{2}{*}{ Treatments } & \multicolumn{2}{|c|}{$\begin{array}{l}\text { Days from transplanting } \\
\text { to }\end{array}$} & \multirow{2}{*}{$\begin{array}{l}\text { Plant } \\
\text { Height } \\
(\mathrm{cm})\end{array}$} & \multirow{2}{*}{$\begin{array}{l}\text { Leaf } \\
\text { Area } \\
\text { Index }\end{array}$} & \multirow{2}{*}{$\begin{array}{c}\text { Fresh } \\
\text { Straw } \\
\text { Yield } \\
\left(\mathrm{t} \mathrm{ha}^{-1}\right) \\
\end{array}$} \\
\hline & Heading & Maturity & & & \\
\hline $\mathrm{T}_{1}=$ Masipag $45(\mathrm{M} 45)$ & $68.33 \mathrm{c}$ & $98.33 \mathbf{c}$ & 127.10 & 4.30 & $18.35 \mathbf{b}$ \\
\hline $\mathrm{T}_{2}=$ Matatag $6(\mathrm{M} 6)$ & $61.00 \mathrm{e}$ & $91.00 \mathbf{e}$ & 113.95 & 4.07 & $17.61 \mathbf{b}$ \\
\hline $\begin{array}{l}T_{3}=\text { Masipag 129-2 (M129- } \\
\text { 2) }\end{array}$ & $71.33 \mathbf{b}$ & $101.33 \mathbf{b}$ & 119.44 & 4.03 & $20.56 \mathbf{a b}$ \\
\hline $\mathrm{T}_{4}=$ Pinili $1(\mathrm{P} 1)$ & $51.67 \mathbf{f}$ & $81.67 \mathbf{f}$ & 123.12 & 3.96 & $20.67 \mathbf{a b}$ \\
\hline $\mathrm{T}_{5}=\mathrm{SL}-8 \mathrm{H}$ (hybrid) & $66.33 \mathbf{d}$ & $96.33 \mathbf{d}$ & 116.19 & 4.24 & $18.26 \mathbf{b}$ \\
\hline 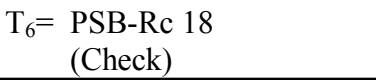 & $73.00 \mathbf{a}$ & $103.00 \mathrm{a}$ & 121.34 & 4.20 & $22.84 \mathbf{a}$ \\
\hline C.V. $(\%)$ & 0.54 & 0.37 & 4.20 & 2.97 & 9.63 \\
\hline
\end{tabular}


Yield, Yield Components, and Harvest Index

Of the six yield-related parameters studied, only the number of productive tillers per hill, number of filled grains per panicle and grain yield in tons per hectare differed significantly among treatments $(p<0.05)$ (Table 3). The variations observed in the yield components could be attributed to inherent varietal differences. PSB Rc-18 (check variety) produced the highest number of productive tillers per hill, but it was comparable to varieties M-129-2, Matatag 6, Pinili 1, and M-45. SL-8H had the least number of productive tillers/hill. On the other hand, M129-2 produced the highest number of filled grains per panicle, although it did not differ significantly to the number of filled grains per panicle of PSB-Rc18. The lowest number of filled grains per panicle was obtained from Pinili-1 variety. A high coefficient of variation (CV) was observed in this parameter $(33.31 \%)$ probably due to the effect of tungro infection experienced by some of the test varieties (Pinili-1, Matatag 45 and SL$8 \mathrm{H})$.

Table 3. Yield and yield components of lowland rice varieties under AWD water management

\begin{tabular}{|c|c|c|c|c|c|c|}
\hline \multirow[b]{2}{*}{ Treatments } & \multicolumn{3}{|c|}{ Number of } & \multirow{2}{*}{$\begin{array}{c}\text { Weight } \\
\text { of } \\
1,000 \\
\text { grains }(\mathrm{g})\end{array}$} & \multirow{2}{*}{$\begin{array}{l}\text { Grain } \\
\text { Yield } \\
(\mathrm{t} \mathrm{ha-1})\end{array}$} & \multirow{2}{*}{$\begin{array}{c}\text { Harvest } \\
\text { Index }\end{array}$} \\
\hline & $\begin{array}{l}\text { Produc- } \\
\text { tive } \\
\text { tillers/hill }\end{array}$ & $\begin{array}{c}\text { Filled } \\
\text { grains/ } \\
\text { panicle }\end{array}$ & $\begin{array}{c}\text { Unfilled } \\
\text { grains/ } \\
\text { panicle }\end{array}$ & & & \\
\hline $\mathrm{T}_{1}=\underset{(\mathrm{M} 45)}{\operatorname{Masipag}} 45$ & 9.27 abc & $38.40 \mathbf{b c}$ & 43.53 & 22.27 & $0.88 \mathbf{b}$ & 0.16 \\
\hline $\mathrm{T}_{2}=$ Matatag $6(\mathrm{M} 6)$ & 9.80 abc & 55.47 bc & 25.40 & 26.20 & $2.84 \mathbf{a}$ & 0.22 \\
\hline $\begin{array}{c}\mathrm{T}_{3}=\text { Masipag 192-2 } \\
(\mathrm{M} 129-2)\end{array}$ & $16.00 \mathbf{a b}$ & $123.60 \mathbf{a}$ & 36.27 & 27.43 & $3.29 \mathbf{a}$ & 0.30 \\
\hline $\mathrm{T}_{4}=$ Pinili-1 $(\mathrm{P} 1)$ & $8.67 \mathbf{a b c}$ & $23.90 \mathbf{b c}$ & 47.07 & 20.67 & $0.93 \mathbf{b}$ & 0.19 \\
\hline $\mathrm{T}_{5}=\mathrm{SL}-8 \mathrm{H}$ (hybrid) & $7.13 \mathrm{c}$ & $63.60 \mathrm{~b}$ & 55.33 & 23.37 & $1.05 \mathrm{~b}$ & 0.15 \\
\hline $\begin{array}{c}\mathrm{T}_{6}=\text { PSB-Rc18 } \\
\text { (Check) }\end{array}$ & $16.53 \mathbf{a}$ & $111.40 \mathbf{a b}$ & 46.53 & 27.00 & $2.21 \mathbf{a b}$ & 0.21 \\
\hline C.V. $(\%)$ & 23.81 & 33.31 & 44.63 & 15.00 & 27.21 & 31.45 \\
\hline
\end{tabular}


In terms of grain yield, SL-8H, Pinili-1, and M-45 obtained the lowest grain yields due to tungro that affected the overall performance of these varieties. However, M-129-2 obtained the highest grain yield, but it was not significantly different from those of Matatag 6 and PSB-Rc18. These results suggest that M-129-2, Matatag 6, and PSB-Rc18 varieties were adaptable to the growing condition brought about by AWD water management system. As found out by Escasinas (2009), these varieties have better root system than the other varieties. These roots may have been able to grow vigorously and were able to absorb greater amount of water and nutrient elements in the soil. This resulted in the continuous supply of essential elements needed during the plants' reproductive stage and eventually led to more number of filled grains produced per panicle hence, higher grain yields than the other test varieties.

\section{Cost and Return Analysis}

Results of the economic analysis revealed that M-129-2 and Matag 6 have no significant differences on grain yield, so their mean was used to determine the income. Highest net return of Php23,805.00 per hectare was obtained from these two test varieties (Table 4). These varieties were observed to be more adaptable to AWD water management system and were resistant to common insect pests (like army worms, green leafhoppers and stemborers) and diseases (like bacterial leaf blight, brown spot and tungro) which consequently resulted in higher grain yield. The other varieties, specifically SL-8H (hybrid), Pinili-1, and Masipag-45 were susceptible to insect pests and diseases, particularly to bacterial leaf blight and tungro virus, respectively, resulting in negative net returns. Masipag 45, Pinili-1, and SL-8H had the highest net loss of Php14,355.00. This suggests that these three varieties were not adaptable to AWD water management system. 
Table 4. Production cost and returns analysis of lowland rice varieties per hectare under AWD water management.

\begin{tabular}{|c|c|c|c|c|c|}
\hline Treatment & $\begin{array}{l}\text { Actual Grain } \\
\text { Yield }\left(\mathrm{t} \mathrm{ha}^{-1}\right)\end{array}$ & $\begin{array}{l}\text { Mean Grain } \\
\text { Yield }\left(\mathrm{t} \mathrm{ha}^{-1}\right)\end{array}$ & $\begin{array}{l}\text { Gross } \\
\text { Income } \\
(\mathrm{Php})^{1}\end{array}$ & $\begin{array}{c}\text { Gross } \\
\text { Expenses } \\
(\text { Php) }\end{array}$ & $\begin{array}{l}\text { Net Income } \\
\quad(\text { Php) }\end{array}$ \\
\hline $\mathrm{T}_{1}=$ Masipag $45(\mathrm{M} 45)$ & $0.88 \mathbf{b}$ & 0.95 & $17,100.00$ & $31,455.00$ & $-14,355.00$ \\
\hline $\mathrm{T}_{2}=$ Matatag $6(\mathrm{M} 6)$ & $2.84 \mathbf{a}$ & 3.07 & $55,260.00$ & $31,455.00$ & $23,805.00$ \\
\hline $\begin{array}{c}\mathrm{T}_{3}=\text { Masipag 129-2 } \\
(\mathrm{M} 129-2)\end{array}$ & $3.29 \mathbf{a}$ & 3.07 & $55,260.00$ & $31,455.00$ & $23,805.00$ \\
\hline T4= Pinili -1 & $0.93 \mathbf{b}$ & 0.95 & $17,100.00$ & $31,455.00$ & $-14,355.00$ \\
\hline T5= SL-8H (hybrid) & $1.05 \mathbf{b}$ & 0.95 & $17,100.00$ & $31,455.00$ & $-14,355.00$ \\
\hline $\mathrm{T} 6=\mathrm{PSB}-\mathrm{Rc} 18$ (check) & $2.21 \mathbf{a b}$ & 2.21 & $39,780.00$ & $31,455.00$ & $8,325.00$ \\
\hline
\end{tabular}

${ }^{1}$ Computed based on the mean grain yield

\section{CONCLUSION}

Based on the results of this study, it can be concluded that among the rice varieties tested, M-129-2 and Matatag 6 had the highest number of productive tillers per hill and number of filled grains per panicle thus, the highest grain yield $\left(\mathrm{t} \mathrm{ha}^{-1}\right)$ which were comparable to the check variety (PSB Rc 18). This resulted in the highest net return of Php 23,805.00. Thus, it can be concluded further that among the rice varieties tested, M-129-2 and Matatag 6 are the ones that are best suited for AWD system of rice production.

\section{REFERENCES}

AKITA, S. 1987. Progress in Irrigated Rice Research. IRRI. Los Banos, Laguna. Philippines. $41 \mathrm{p}$.

BELDER, P., B. A. M. BOUMAN, J. H. SPIERTZ, and R. TOUNG. 2004. Effect of water and nitrogen management on wateruse efficiency and yield of irrigated rice. Agricultural Water Management 65:193-210. 
CAINTIC, F. M. S. 2004. Comparative performance of hybrid and inbred lowland rice varieties under Western Leyte Conditions. Undergrad. Thesis, LSU, Visca, Baybay, Leyte. 61 pp.

ESCASINAS, R. O. 2009. Physiological, morphological and agronomic responses of lowland rice (Oryza sativa L.) to organic production system and alternative water management practices. Unpublished PhD Thesis, UPLB, College, Laguna, Philippines. 163 pp.

FACON, T. 2000. Water management in rice in Asia: Some issues in the future. In: Bridging the Rice Yield Gap in the Asia-Pacific Region (M. K. Papademetriou, F. J. Dent, and E. M. Herath, eds). FAO/RAP, Thailand.

IRRI. 1997. Rice Almanac (2nd ed). Los Banos, Laguna, Philippines: International Rice Research Institute. 181 pp.

LAMPAYAN, R. M., B. A. M. BOUMAN, J. L. DE DIOS, A. T. LACTAOEN, A. J. ESPIRITU, T. M. NORTE, E. J. P. QUILANG, D. F. TABBALL, L. P. LLORCA, J. B. SORIANO, A. A. CORPUZ, R. B. MALASA, and V. R. VICMUDO. 2004. Adoption of Water Saving Technologies in Rice Production in the Philippines. Retrieved April 16, 2011 from http://www. agnet.org/library/eb/548/

PCARRD. 1980. Standard Methods of Analysis for Soil, Plant Tissue, Water and Fertilizer. Los Banos, Laguna, Phlippines: PCARRD. $109 \mathrm{pp}$.

TRIPOLI, M. A. B. 2006. Performance of lowland rice under different water management system and number of transplanted seedlings per hill. Undergrad. Thesis. LSU, Visca, Baybay, Leyte. 61 pp.

VIAL, L. 2007. Growing rice with less water. IREC Farmers 'Newsletter, No. 176, Spring 2007. pp. 1-45. 
VIRK, P., S. S. VERMANI, V. LOPENA, and R. CABANGON. 2004. Enhancing water productivity in irrigated rice. In: New directions for a diverse planet: Proceedings for the 4th International Crop Science Congress (T. Fischer et al. eds). Brisbane, Australia, 26 September - 1 October 2004. 